University of Rhode Island

DigitalCommons@URI

The Rhode Island Current Conditions Index

Economics

$12-2005$

\title{
Rhode Island Current Conditions Index - December 2005
}

Leonard Lardaro

University of Rhode Island, lardaro@uri.edu

Follow this and additional works at: https://digitalcommons.uri.edu/ricci

Part of the Econometrics Commons

Terms of Use

All rights reserved under copyright.

\section{Recommended Citation}

Lardaro, Leonard, "Rhode Island Current Conditions Index -- December 2005" (2005). The Rhode Island Current Conditions Index. Paper 95.

https://digitalcommons.uri.edu/ricci/95

This Article is brought to you for free and open access by the Economics at DigitalCommons@URI. It has been accepted for inclusion in The Rhode Island Current Conditions Index by an authorized administrator of DigitalCommons@URI.For more information, please contact digitalcommons-group@uri.edu. 


\section{CURRENT}

Rhode Island's economy finished the year in much the same way as it had progressed through 2005 - stuck in first gear. The December Current Conditions Index was 58, with seven of the twelve indicators improving. December marked the seventh time the $\mathrm{CCl}$ attained this value in 2005. There were two strong indicator performances in December, relating to layoffs and long-term unemployment. Overall, however, the entire set of indicators failed to display much in terms of either strong underlying momentum or signs of a likely growth spurt in the months to come.

The best performers this month were Benefit Exhaustions, which reflects long-term unemployment, and New Claims, a measure of layoffs. Benefit Exhaustions declined by a dramatic 19.6 percent compared to last December, indicating a sharp reduction in longer-term unemployment. December's decline was the third double-digit decline for this indicator in

\begin{tabular}{lc}
\multicolumn{2}{c}{ CCI Indicators - \% Change } \\
Government Employment & 0.5 Y \\
US Consumer Sentiment & -5.8 \\
Single-Unit Permits & 6.9 Y \\
Retail Sales & -3.1 \\
Help Wanted Advertising & -0.1 \\
Priv. Serv-Prod Employment & $1.5 \mathbf{Y}$ \\
Total Manufacturing Hours & -5.0 \\
Manufacturing Wage & $1.6 \mathbf{Y}$ \\
Labor Force & $3.7 \mathbf{Y}$ \\
Benefit Exhaustions & $-19.6 \mathbf{Y}$ \\
New Claims & $-5.9 \mathbf{Y}$ \\
Unemployment Rate & 8.3 \\
\multicolumn{1}{|c}{$\mathbf{Y}=$ I mproved Value } &
\end{tabular}

the last four months. New Claims for Unemployment Insurance fell by 5.9 percent, the eighth consecutive month for which this indicator has improved. The recent strong performances by these two indicators is somewhat surprising, since labor demand, measured by Help Wanted Advertising, has clearly weakened throughout the second half of the year. For December, Help Wanted Advertising fell by 0.1 percent, a relatively small decline to be sure, but this was its second decline in the last three months, reflecting further deterioration of its upward trend.

A couple of other indicators displayed fairly strong rates of growth in December, although some of their momentum was attributable to other factors. Single-Unit Permits, which reflect new home construction, grew by 6.9 percent compared with last December. Part of this increase is the result of unseasonably warm weather this December. While this indicator has been on somewhat of a roller coaster ride this past year, several additional increases will be needed before it is reasonable to conclude that its downtrend has reversed. Our Labor Force also grew rapidly, 3.7 percent in December. But this large growth rate is the result of a weak "comp" last December in a year that saw sharp declines in both our Labor Force and Resident Employment. In light of this strong Labor Force growth, the rise in our Unemployment Rate compared to last December is not as problematic as it would be had our Labor Force actually declined (as it did through 2004).

Retail Sales fell by 3.1 percent in December, marking the conclusion of a modest holiday shopping season. Weakness in this indicator was bolstered by yet another decline in US Consumer Sentiment, which fell by 5.8 percent. Retail Sales momentum here, like the nation, has moderated, partly as a result of a weakening housing sector.

Government Employment rose in December (by 0.5\%), something we will see less of as budget tightening progresses. At the same time, Private Service-Producing Employment grew by 1.5 percent, its slowest rate of growth since May. Weakness in our goods-producing sector continued, as the rate of decline in Total Manufacturing Hours accelerated to 5 percent, its most rapid rate of decrease since August. As this was occurring, the Manufacturing Wage grew by 1.6 percent, sustaining recent rates of growth.

Like the nation, Rhode Island witnessed disappointing growth in the fourth quarter of 2005. Nationally, real GDP growth slowed from 4.1 percent in Q3 to 1.1 percent in Q4, a noticeable drop-off. Unlike the nation, Rhode Island's disappointment was the continuation of a slow pace of economic activity that persisted throughout the entire year.

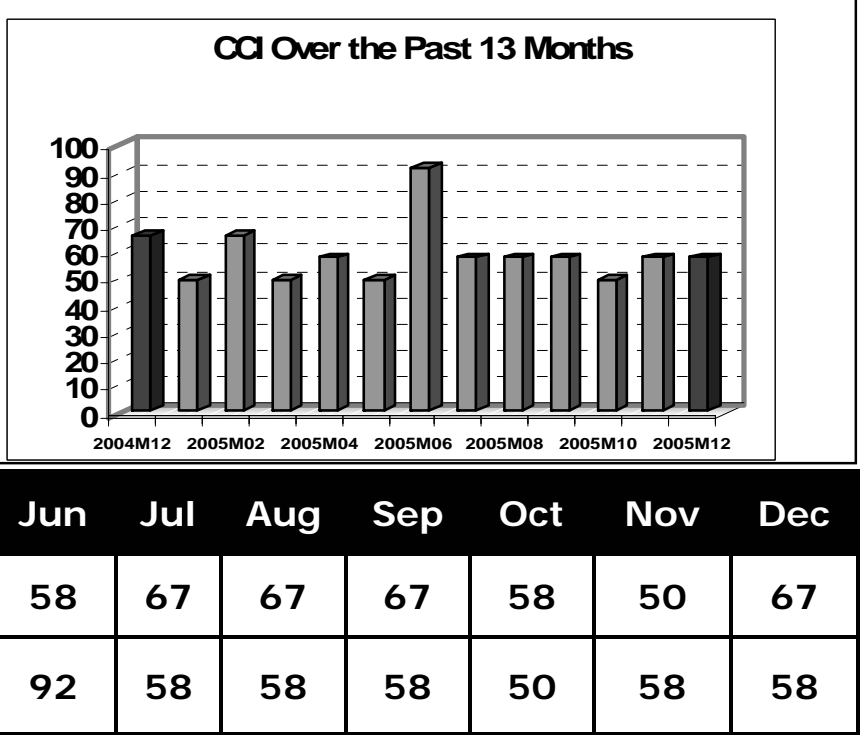

